\title{
(1) Pulmonary Tuberculosis in a Patient with Marfan's Syndrome with Pulmonary Involvement
}

\author{
Marfan Sendromu Akciğer Tutulumu Bulunan Olguda Akciğer Tüberkülozu
}

Fikret Kanat, Baykal Tülek

\begin{abstract}
Marfan's syndrome (MFS) is a connective tissue disorder inherited by autosomal dominance and primarily affecting the ocular, musculoskeletal, and cardiovascular systems. Its pulmonary manifestations, such as spontaneous pneumothorax, apical blebs, and bullae, are rarely seen. We present a young male patient, incidentally diagnosed with MFS, while under treatment for chronic pulmonary tuberculosis. Apical parenchymal involvement of MFS and pulmonary tuberculosis were discussed.
\end{abstract}

Key words: Marfan's Syndrome, lung, tuberculosis.

\section{Özet}

Marfan sendromu (MFS) otozomal dominant geçiş gösteren öncelikle oküler, kas-iskelet ve kardiyovasküler sistemleri tutan bir bağ dokusu hastalığıdır. Hastalığın; spontan pnömotoraks, apikal bül veya blebler gibi akciğer belirtileriyle nadiren karşılaşılır. Bu sunumda kronik akciğer tüberkülozu tedavisi altında iken rastlantısal olarak MFS tanısı konulan genç bir erkek hasta sunuldu. MFS'nin apikal parankim tutulumu ve akciğer tüberkülozu tartışıldı.

Anahtar Sözcükler: Marfan Sendromu, akciğer, tüberküloz.

Department of Chest Diseases, Selçuk University Faculty of

Selçuk Universitesi Tıp Fakültesi, Göğüs Hastalıkları Anabilim Medicine Konya, Turkey Dalı, Konya

Su bmitted (Başvuru tarihi): 05.09.2012 Accepted (Kabul tarihi): 01.01.2013

Correspondence (iletişim): Baykal Tülek, Department of Chest Diseases, Selçuk University Faculty of Medicine, Konya, Turkey e-mail: baykaltulek@yahoo.com 
Marfan's syndrome (MFS) is an inherited connective tissue disorder transmitted as an autosomal dominant trait $(1,2)$. We present a patient with chronic active tuberculosis, diagnosed with MFS by coincidence and discuss whether the apical radiological findings are secondary to tuberculosis or pulmonary involvement of MFS.

\section{CASE}

A 22-year-old male patient was admitted with chest pain and hemoptysis. Past history revealed spontaneous pneumothorax treated with closed tube drainage 3 years prior. He was under irregular antituberculous treatment for smear and culture positive tuberculosis for 2 years. The patient was smear positive and hospitalized for active tuberculosis in our clinic. Retreatment with isoniazid, rifampin, pyrazinamide, ethambutol and streptomycin was started. Family history revealed that the patient's sister, brother, mother, aunt and uncle died of sudden death in their early years. Upon physical examination, the patient was hypertensive (blood pressure: 155/90 mmHg), very tall (height: $192 \mathrm{~cm}$ ), cachectic (weight: $52 \mathrm{~kg}$ ), and pale in appearance (Figure 1A). Arachnodactyly and hypermotility of the joints were present (Figure 1B, 1C). Chest examination revealed scoliosis, pectus excavatum and normal pulmonary sounds. The routine laboratory examination was within normal limits. Chest $x$-ray revealed a cavity in the left upper zone. Chest HRCT showed bilateral apical bullae and blebs, a cavity in the left upper lobe and bilateral bronchogenic infiltrations (Figure 2). The presence of scoliosis, pectus excavatum, arachnodactyly, hypermobility of joints, and early sudden deaths in the patient's family attracted our attention. The patient had a unique face, dental crowding, a highly arched palate (Figure 1D), dolichocephaly, malar hypoplasia, enophthalmos, and down-slanting palpebral fissures were apparent on the face. These findings guided us to consider an inherited connective tissue disorder, MFS. Therefore other system manifestations of the syndrome were investigated. An eye examination revealed lens dislocation and myopia. Echocardiography disclosed mitral valve prolapse and MRI revealed dural ectasia in the lumbosacral spine. The patient, whose sputum culture was positive for Mycobacterium Tuberculosis, continues to receive antituberculous treatment.

\section{DISCUSSION}

Diagnosis of MFS is made using a set of diagnostic criteria, which is based on the evaluation of familial history, molecular data, and various organ systems $(1,3)$.

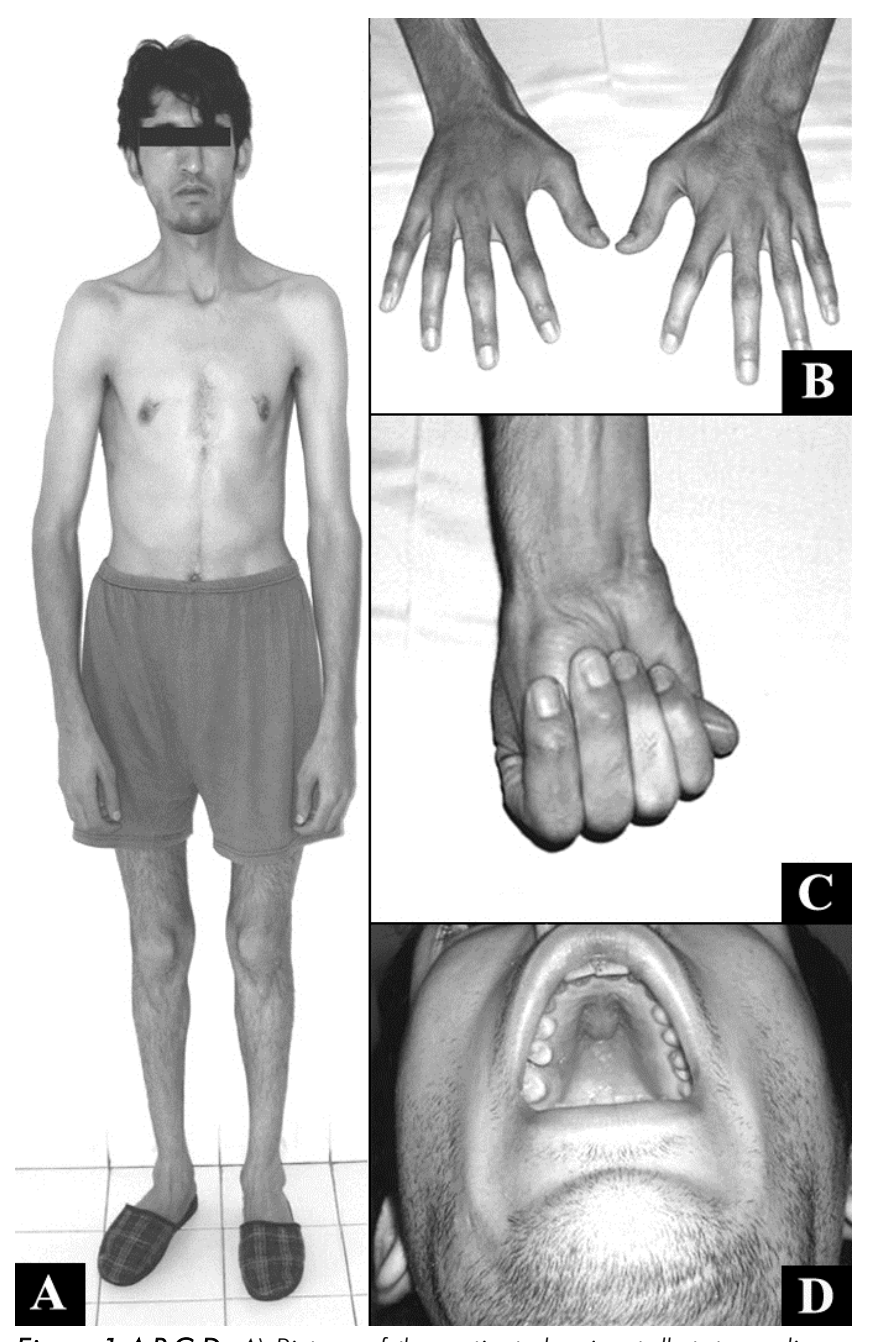

Figure $1 A, B, C, D:$ A) Picture of the patient showing tall stature, disproportionate limbs, reduced upper-to-lower body segments ratio, pectus excavatum, and reduced extension of elbows, dolichocephaly and malar hypoplasia, B) Arachnodactyly. C) Positive wrist sign (Steinberg sign: a sign of hypermobility), D) High arched palate and dental crowding.

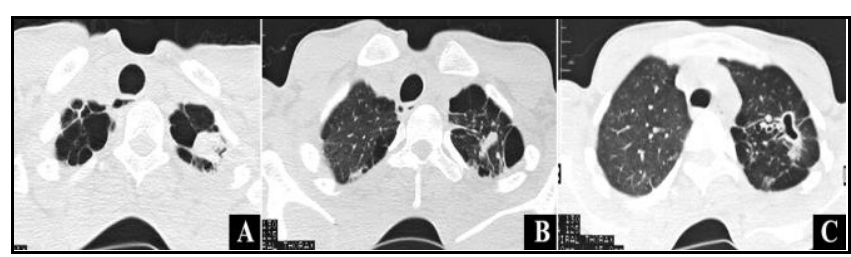

Figure $2 A, B, C: A)$ Chest HRCT of the patient showing bilateral apical bullae and blebs, B) Concurrent parenchymal scarring in the left apex and bullae C) A thick-walled parenchymal tuberculosis cavity in the left upperlobe.

According to the "Ghent criteria", established in 1996, major and minor criteria are described. There were three major criteria, in addition to family history, in our patient. Ectopia lentis, lumbosacral dural ectasia, and skeletal system criteria were the major findings.

For the pulmonary system, only minor criteria are noted in MFS, which include spontaneous pneumothorax, apical bullae, and blebs (1). Spontaneous pneumothorax is the most frequently reported pulmonary abnormality in pa- 
tients with MFS (4). This complication arises in $5-10 \%$ of the patients (5). Spontaneous pneumothorax appears to be caused by the rupture of an air-containing space such as bullae or blebs. Bullae are defined as a sharply demarcated region of emphysema greater than $1 \mathrm{~cm}$ in diameter and blebs are focal gas-containing spaces situated entirely within the visceral pleura. Bullae occur more commonly in association with other diseases, typically emphysema or infection. In the latter condition, parenchymal scarring is frequent (6). In our patient HRCT disclosed bilateral apical bullae and blebs. The patient's three-year history of pulmonary tuberculosis may cause a question of whether apical bullae are secondary to tuberculosis or the present condition is the other pulmonary manifestation of the syndrome. Tuberculosis infection leads among the diseases established at the pulmonary apex and apical infiltrations. Tuberculosis may complicate with parenchymal scarring including fibrotic bands or bullae during healing process. Marfan's syndrome may also cause apical bullae and blebs due to the deficient fibrillin deposition leading to reduced structural integrity of the lung airways $(4,5)$. In our patient we consider that the apical bullae are secondary to MFS. The first evidence comes from the timing of spontaneous pneumothorax, which may confirm that apical blebs or bullae have already developed. The second set of evidence is the bilateral apical involvement. HRCT scan of the patient has demonstrated bilateral apical bullae and blebs. The presence of parenchymal scarring on the left apex only and no parenchymal scarring on the right apex strengthens this opinion.

We encountered three previous reports in the literature noting the accidental association of tuberculosis with MFS (7-9). There is no mention of the pulmonary involvement of MFS.

It may be important to note that in a patient with chronic pulmonary tuberculosis, the presence of apical bullae and blebs, which are the predominant pulmonary findings in MFS, may cause underdiagnosed pulmonary involvement of the syndrome. Conversely, pulmonary involve- ment of MFS may shadow coincidental active pulmonary tuberculosis, as well. The clinical characteristics of MFS may establish, within a certain period time or prior, that it may not be possible to diagnose. The minor criteria in different organ systems may direct one to search for a connective tissue disorder, as was the case in our patient.

\section{CONFLICTS OF INTEREST}

None declared.

\section{REFERENCES}

1. De Paepe A, Devereux RB, Dietz HC, Hennekam RC, Pyeritz RE. Revised diagnostic criteria for Marfan syndrome. Am J Med Genet 1996; 62:417-26. [CrossRef]

2. Gencer M, Ceylan E. Marfan Sendromlu hastada primer pulmoner hipertansiyon ve tekrarlayan masif plevral sıvı: Olgu Sunumu. Akciğer Arşivi 2006; 7:125-7.

3. De Paepe A. Dural ectasia and the diagnosis of Marfan's syndrome. Lancet 1999; 354:878-9. [CrossRef]

4. Wood JR, Bellamy D, Child AH, Citron KM. Pulmonary disease in patients with Marfan syndrome. Thorax 1984; 39:780-4. [CrossRef]

5. Hall JR, Pyeritz RE, Dudgeon DL, Haller JA Jr. Pneumothorax in the Marfan syndrome: prevalence and therapy. Ann Thorac Surg 1984; 37:500-4. [CrossRef]

6. Tsukerman Gla, Shmelev EN, Kovalev MD. Marfan's syndrome complicated by fibrous-cavernous pulmonary tuberculosis and aspergillosis. Probl Tuberk 1982; 11:72-3.

7. Jain VK, Kumar P, Beniwal OP, Pareek RP. Pulmonary tuberculosis in Marfan's syndrome. J Indian Med Assoc 1986; 84:119-20.

8. Khanna BK, Prasad R. Chronic pulmonary tuberculosis in Marfan syndrome. Indian J Chest Dis Allied Sci 1980; 22:251-4.

9. Fraser RS, Müller NL, Colman N, Pare PD. Decreased lung density. In: Fraser RS, Müller NL, Colman N, Pare PD, eds. Fraser and Pare's Diagnosis of Diseases of The Chest. 4th ed. Philadelphia: W.B. Saunders Company; 1999:493-512. 